\title{
REDESAIN PERMAINAN TRADISIONAL BAS-BASAN SEPUR
}

\author{
Erik Armayuda ${ }^{1}$, M. Lahandi Baskoro² \\ ${ }^{1,2}$ Desain Komunikasi Visual, Fakultas Industri Kreatif, Universitas Trilogi Jakarta \\ armayuda@universitas-trilogi.ac.id ${ }^{1}$, lahandi@universitas-trilogi.ac.id ${ }^{2}$
}

\begin{abstract}
Abstrak
Indonesia adalah negeri yang kaya akan nilai-nilai budaya dan tradisi. Kekayaan ini sudah seharusnya menjadi sumber inspirasi untuk beragam karya kreatif masa kini. Banyak hal yang dapat dikaji dan dikemas kembali dengan lebih baik untuk menjadi sebuah produk di bidang industri kreatif. Salah satu potensi tersebut adalah permainan tradisional. Melalui proses simulasi berulang untuk memahami karakter permainan, lalu mengkombinasikanya dengan kebutuhan pasar board game yang relevan, diharapkan dapat menemukan sebuah bentuk transformasi yang sesuai dengan perkembangan zaman sebagai bagian dari produk industri kreatif. Penelitian ini bertujuan untuk menemukan pakem dari sebuah permainan tradisional dan unsur terkait yang membentuk permainan tersebut, sehingga dalam proses pengembangan dalam konteks redesain, permainan hasil proses redesain akan tetap memiliki karakter serta nilai yang sama dari permainan aslinya namun masih relevan dengan kebutuhan pasar di jaman ini.
\end{abstract}

Kata Kunci: permainan tradisional, transformasi budaya, redesain

\begin{abstract}
Indonesia is a country rich in cultural values and traditions. This wealth should be a source of inspiration for a variety of creative works today. Much can be reviewed and repacked better to become a product in the field of creative industry. One such potential is the traditional game. Through a recurring simulation process to understand the character of the game, then combine it with the relevant board game market needs, it is expected to find a form of transformation that fits the times as part of the creative industry product. This study aims to find the grip of a traditional game and related elements that make up the game, so that in the development process in the redesign context, the redesigned game will still have the same character and value of the original game, but still relevant with now day's market needs.
\end{abstract}

Keywords: traditional games, cultural transformation, redesign 


\section{PENDAHULUAN}

Indonesia memiliki potensi keanekaragaman budaya untuk dikembangkan sebagai produk kreatif dalam konteks industri kreatif. Di pasar global - era desain lokal, hubungan antara budaya lokal, pasar global, dan produk inovatif dalam strategi perancangan semakin dekat (Lin, 2012). Salah satu contohnya adalah permainan tradisional yang tersebar dari Sabang sampai Merauke di mana setiap jenisnya memiliki keunikan yang berbeda. Banyak permainan tradisional yang merupakan warisan dari leluhur terdahulu, mengandung nilai edukasi dan moril yang bagus di setiap bentuk permainanya. Namun sayang, kebanyakan permainan tradisional tersebut kurang terekspose dan jarang diperhatikan sebagai potensi produk yang dapat dikembangkan dalam ranah industri kreatif. Padahal menurut Lin (2016), Sementara pasar menuju "globalisasi", desain cenderung menuju "lokalisasi".

Beberapa upaya untuk mempopulerkan kembali permainan tradisional telah dilakukan, tidak sedikit yang menggunakan media digital untuk mengemasnya. Di antaranya adalah penelitian yang telah dilakukan oleh Khamadi, Sihombing, dan Ahmad (2015) dengan permainan bas-basan sepur, Khamadi dan Senoprabowo (2016) dengan permainan macanan, serta Ralibi (2016) dengan dodombaan. Di satu sisi permainan tradisional akan nampak lebih interaktif dan menarik dimainkan untuk anak-anak yang sudah tidak asing lagi dengan dunia digital. Namun di sisi lain, ada beberapa nilai yang hilang, termasuk nilai interaksi sosial karena pemain hanya berinteraksi melalui perangkat digital. Salah satu permainan tradisional yang kaya akan nilai edukasi di dalamnya adalah Bas-basan Sepur yang berasal dari daerah Yogyakarta. Permainan ini sudah jarang diketahui oleh masyarakat, terutama kalangan muda-mudi. Berdasarkan survei yang dilakukan oleh peneliti pada tahun 2016 di Jogjakarta dengan sebagian besar responden anak-anak kelas 4-6 di SD Muhamadiyah Condong Catur dan Sekolah Internasional Kinderstation ditemukan bahwa hanya $5,6 \%$ saja yang pernah mengetahui permainan ini.
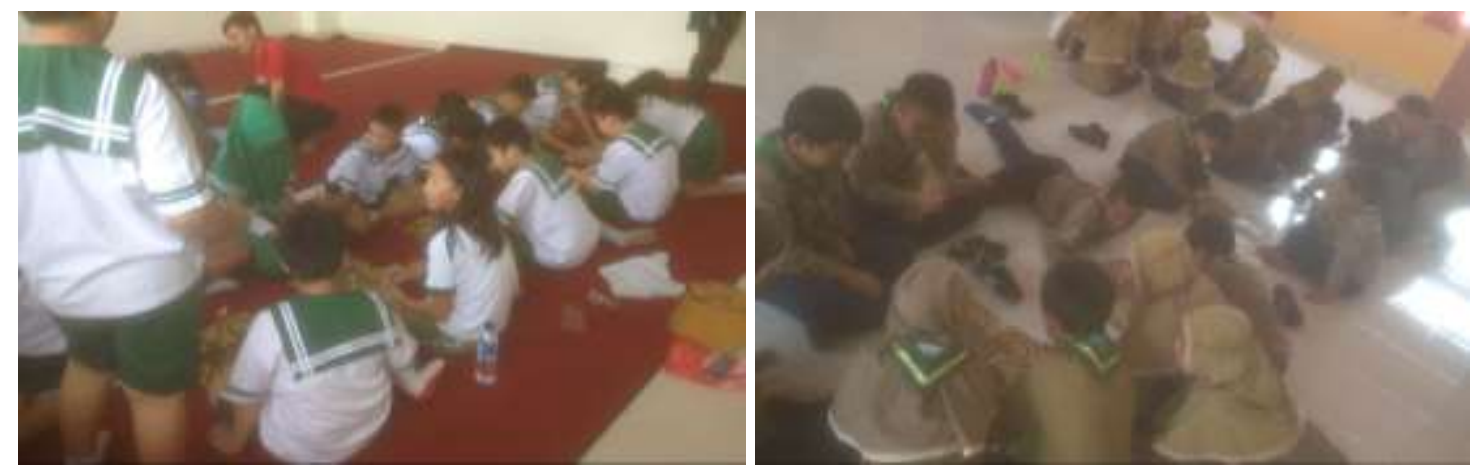

Gambar 1. (kiri) Kegiatan bermain dengan segmentasi anak SD kelas 5-6 di sekolah Internasional Kinderstation dan (kanan) SD Muhamadiyah Condong Catur

[Sumber: Penulis]

Penelitian terkait upaya mempopulerkan permainan tradisional, khususnya Bas-basan Sepur ini, sebelumnya telah pernah dilakukan oleh Khamadi pada tahun 2013 dalam bentuk tesis. Namun ada perbedaan mendasar yang membuat penelitian ini berbeda 
dengan apa yang dilakukan Khamadi pada penelitian sebelumnya. Jika Khamadi melakukan penelitian dalam upaya melakukan sebuah transformasi budaya dari permainan tradisional menjadi permainan modern dengan kemasan digital. Maka penelitian ini bertujuan untuk menemukan formulasi dalam mengemas ulang bentuk permainan tradisional yang masih relevan dengan zamannya. Sehingga pada akhir dari penelitian ini diharapkan dapat memberikan alternatif solusi dalam mempopulerkan kembali permainan tradisional melalui kemasan baru dalam konsep boardgame/permainan papan. Sehingga dapat disimpulkan perbedaan mendasar dari kedua penelitian tersebt adalah, jika Khamadi berfokus pada konsep pengemasan dalam bentuk digital, penelitian ini berfokus pada konsep pengemasan produk secara artefak (bentuk fisik) yang menjadi satu produk board game nantinya.

\section{Metode Penelitian}

Dari permasalahan di atas terdapat dua inti poin yang akan menjadi pemabahasan ke depanya. Kedua poin itu adalah: 1) Mengetahui penyebab tidak populernya permainan ini. 2) Sedangkan poin kedua adalah tentang bagaimana cara untuk bisa mempopulerkan kembali permainan ini memallui proses redesain. Untuk menjawab permasalahan tersebut, maka peneliti menggunakan dua model teori. Teori tersebut adalah dengan model design thinking yang dirumuskan oleh Brown dan Wyatt (2010), untuk menganalisa penyebab tidak populernya permainan ini. Tim merumuskan sebuah proses pemecahan masalah dalam perancangan desain dengan model Design thingking sebagai berikut:

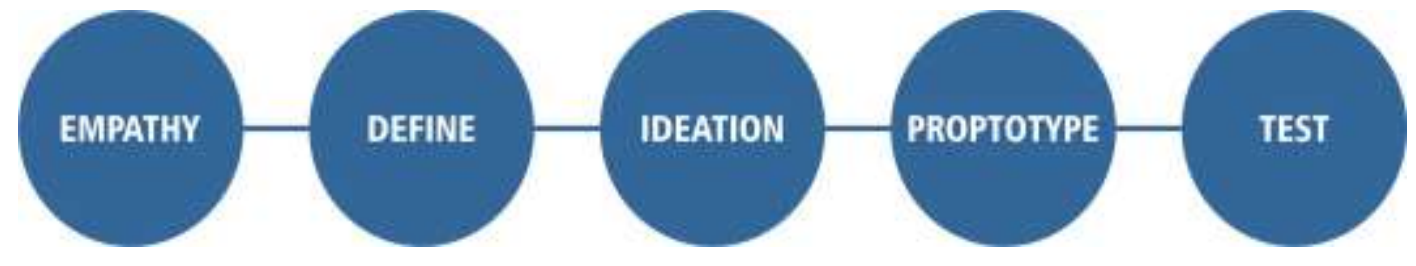

Gambar 2. Model design thinking Tim Brown dan Jocelyn Wyatt

[Sumber: Brown dan Wyatt, 2010]

Sedangkan untuk memberikan alternatif solusi dalam meredesain permainan ini, peneliti menggunakan model ATUMICS (akronim dari kata Artefact, Technique, Utility, Material, Icon, Concept, dan Shape). Metode ini digunakan untuk mengkombinasikan beberapa elemen budaya tradisi dengan beberapa elemen budaya modern pada sebuah desain produk.

Terdapat dua dua level tingkat keberadaan sebuah produk, yaitu level mikro dan level makro. Level mikro terkait dengan sifat penampilan produk yang disusun dari enam elemen dasarnya, yaitu teknik, kegunaan, bahan, ikon, konsep dan bentuk (Technique, Utility, Material, Icon, Concept, Shape). 


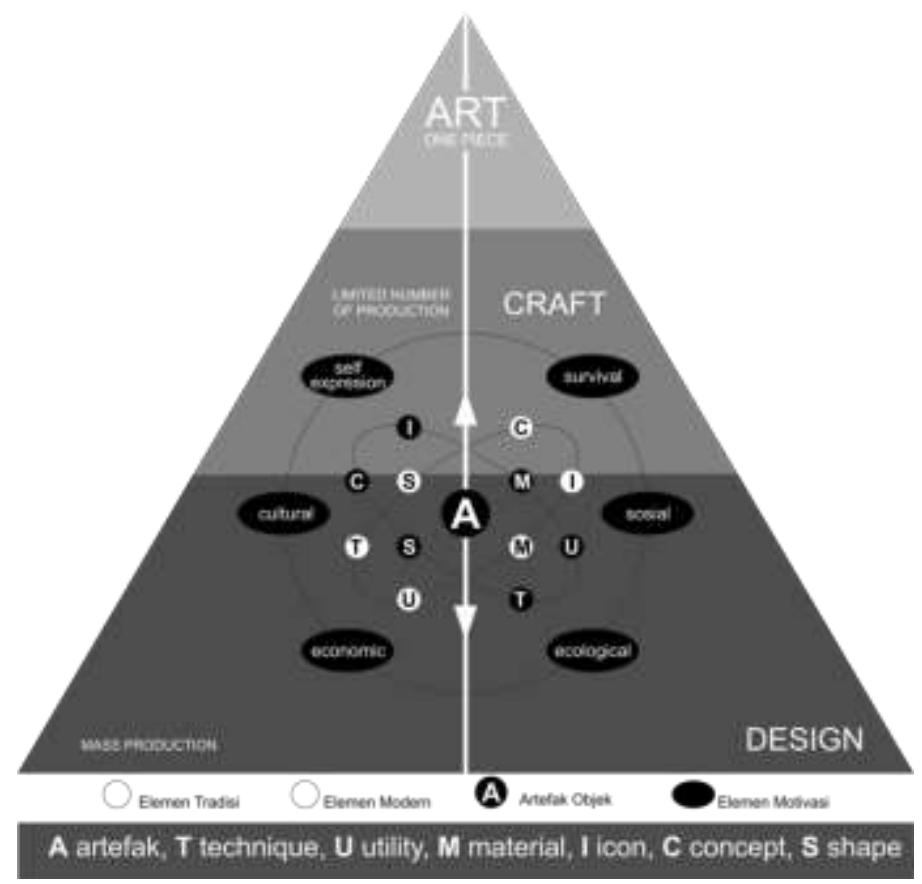

Gambar 3. Bagan transformasi budaya tradisi metode ATUMICS [Sumber: Nugraha, 2012]

Sedangkan level makro, adalah unsur yang terkait dengan hal yang lebih luas dan tak terlihat, seperti semangat dan motivasi di balik produk yang dihasilkan. Hal inilah yang akan terkait dengan aspek sosial, budaya, ekologi, dan ekonomi.

\section{Hasil dan Pembahasan}

\subsection{Permainan Tradisional Bas-basan Sepur}

Menurut Misbah (2007), definisi permainan tradisional adalah perbuatan untuk menghibur hati baik yang menggunakan alat ataupun tidak menggunakan alat. Sedangkan yang dimaksud dengan "tradisional" mengacu pada asal kata "tradisi" yang artinya, "adat kebiasaan turun-menurun yang masih dijalankan". Sehingga kata "tradisional" berarti sikap dan cara berpikir, serta bertindak yang selalu berpegang teguh pada norma dan adat kebiasaan yang ada secara turun temurun". Atau bisa juga diartikan sebagai segala apa yang dituturkan dan diwariskan turun-temurun dari orang tua atau nenek moyang.

Sedangkan permainan Bas-basan Sepur berasal dari kata 'bas-basan', 'bas' diperkirakan berasal dari kependekan kata 'tebas' yang berarti borong, ditebas berarti diborong (bahasa Jawa), biasanya kata tebas dipakai dalam jual beli hasil pertanian. Tetapi jika ditafsirkan dalam cara bermainnya, kata tebas ini bisa dipadankan dengan kata 'serang', sehingga bas-basan atau tebas-tebasan dapat diartikan sebagai permainan yang saling menyerang. Sedangkan Sepur berarti kereta api. Kata Sepur dalam bahasa Jawa ini kiranya serapan dari bahasa Belanda, spoor yang artinya juga 'kereta api'. Sesuai dengan cara mainnya, Sepur disini memperlihatkan jalan alur melingkar pada masing-masing tepi pojok arena permainan. Jadi sesuai dengan laju kereta api, dalam proses memakan uwong (pion permainan) harus melewati setidaknya satu jalan 
melingkar tersebut seolah-olah melalui rel kereta api yang melingkar. (Khamadi et al., 2015)

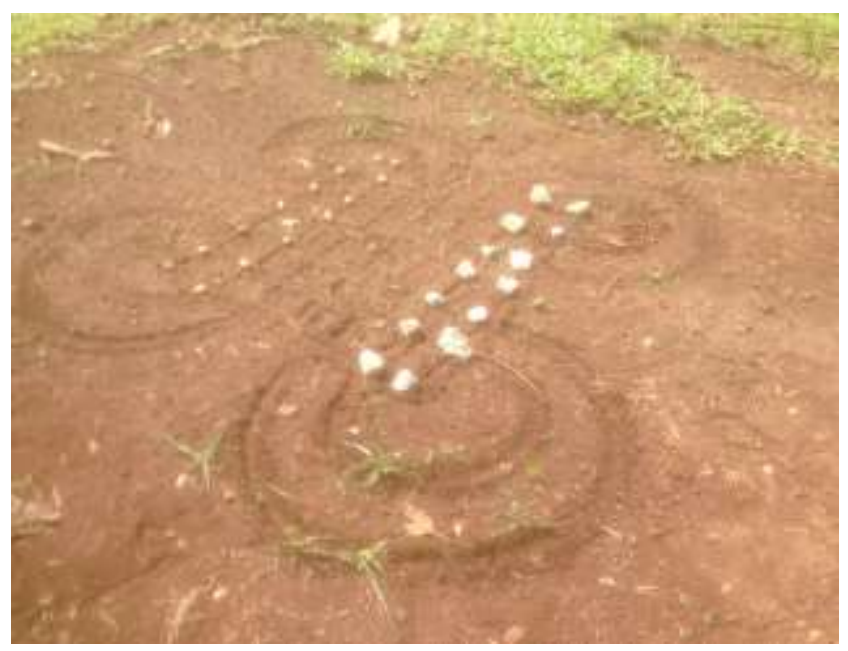

Gambar 4. Bidang permainan Bas-basan Sepur

[Sumber: Penulis]

Permainan ini dimainkan oleh dua orang pemain, yang dulunya biasa dimainkan di atas tanah dengan memggambar pola bidang permainan terlebih dahulu.

\subsection{Analisis Permainan dalam Model Design thinking}

Brown dan Wyatt (2010), menjabarkan bahwa untuk membuat sebuah desain yang relevan dengan penggunanya, diperlukan sebuah proses penelitian yang komprehensif yang dimulai dari proses empati, mendefinisikan masalah, memunculkan ide, membuat prototype, hingga melakukan tes kepada penggunanya. Berikut adalah pembahasan yang mengacu pada metode tersebut.

1. Empathy / Empati

Perumusan analisa untuk tahap empati dilakukan melalui studi interaksi bermain langsung dengan 108 responden 38 mahasiswa, 56 pelajar (SD hingga SMP), 14 sisanya adalah responden umum seperti karyawan dan wiraswasta yang rata-rata berusia di atas 30 tahun. Survei dilakukan pada jangka waktu tahun 2016 yang sebagian besar dilakukan di Jogjakarta dengan sebagian besar responden anak-anak kelas 4-6 di SD Muhamadiyah Condong Catur dan Sekolah Internasional Kinderstation lalu memberi mereka kuisioner terkait penelitian tersebut. Dari aktivitas tersebut didapat data sebagai berikut: 

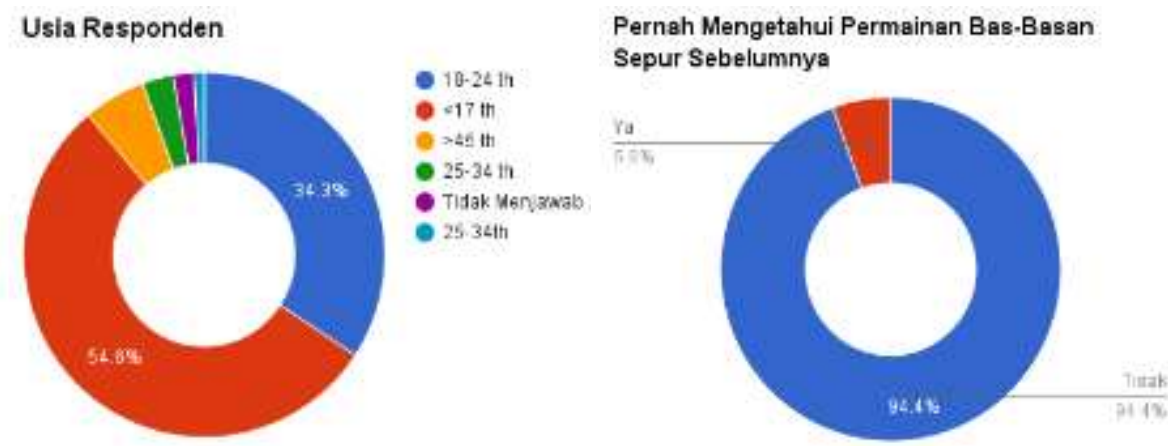

Gambar 5. Hasil data prosentasi demografi responden

[Sumber: Penulis]

94,4\% dari 100 responden yang 54,6\%-nya adalah usia di bawah 17 tahun mengatakan bahwa mereka tidak mengetahui permainan ini, adalah bukti bahwa permainan ini kurang populer di kalangan generasi muda. Dari data itu, diperoleh juga beberapa data kualitatif yang diperoleh melalui dialog antara peneliti dan responden selama melakukan permainan. Dari data kualitatif diperoleh beberapa kesimpulan yang menjadi salah satu penyebab permainan ini kuang populer di antaranya:

1) Belum adanya branding dan pengemasan yang baik sehingga mudah dalam memainkanya dan menyadari keberadaanya. Faktor ini didasari karena permainan ini dulunya dimainkan di atas tanah dengan menggambar pola arena, sedangkan di jaman sekarang anak-anak sebagai segmen permainan ini sudah jarang bermain di arena terbuka. Sehingga pengemasan menjadi sangat penting dalam mengenalkan permainan ini.

2) Dari sisi cara bermain, permainan ini pada dasarnya hampir sama dengan catur, terdapat dua kubu pasukan dengan tujuan akhir adalah untuk menghabiskan pasukan lawan. Namun yang membedakanya dari catur adalah caranya dalam menyerang lawan. Jika di dalam catur tiap bidak memiliki cara melangkah dan menyerang yang berbeda, namun dalam permainan ini, bidak hanya bisa menyerang menggunakan dua jalur serang yang ada, jalur besar yang kecil, dan jalur serang besar.
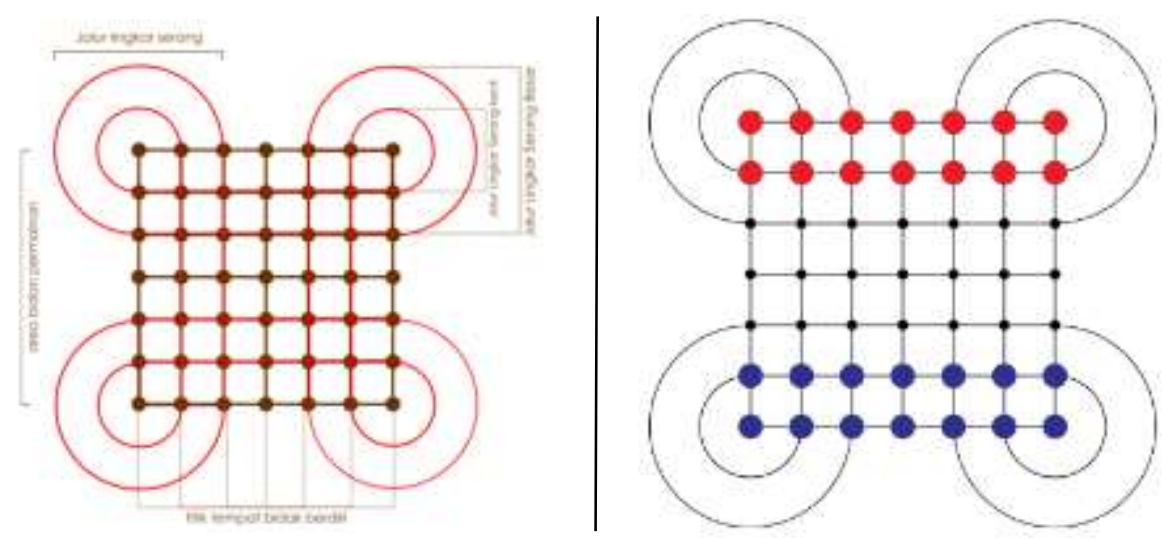

Gambar 6. Keterangan papan permainan dan posisi bidak saat permainan dimulai [Sumber: Penulis] 
Sedangkan untuk memulai permainan, para pemain masing-masing dibekali 14 bidak yang ditata saling berseberangan layaknya permainan catur seperti di atas. Cara memainkan permainan ini dibedakan dengan cara menggunakan jalur serang. Caranya, selama garis dalam jalur tersebut terhubung dengan bidak lawan, dengan cara meniti garis tersebut, bidak yang hendak menyerang lawan melesat hingga menabrak lawan yang ada di jalur serang tersebut, untuk menggantikan posisinya dengan posisi bidak yang menyerang.
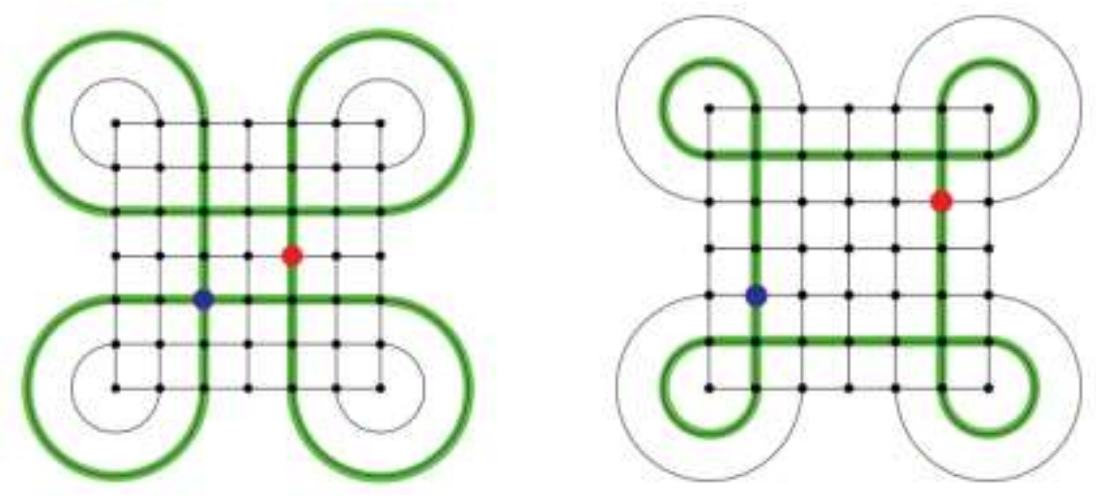

Gambar 7. Jalur serang besar, dan jalur serang kecil.

[Sumber: Penulis]

Dikarenakan permainan ini menggunakan bentuk jalur serang sebagai cara menyerang lawan, maka terdapat beberapa titik yang tidak dilintasi oleh jalur serang yang bisa disebut dengan titik aman. Terdapat 9 titik aman pada papan permainan ini. Di mana titik aman ini memiliki kelebihan dan kekurangan.

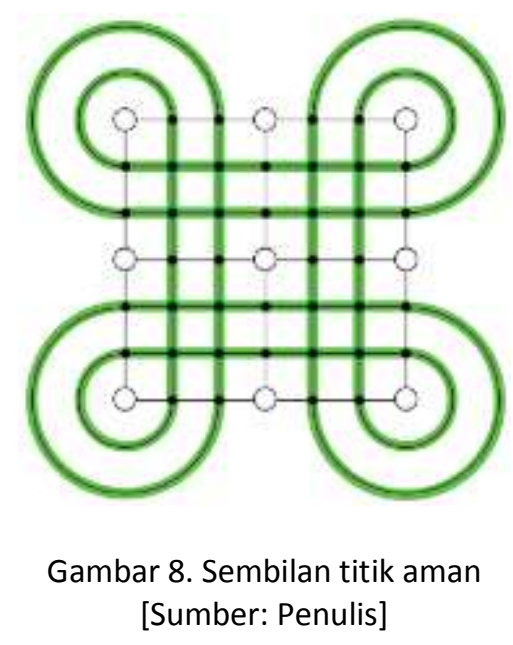

Kelebihan dari titik aman ini tentunya adalah, jika ada bidak yang menempati titik tersebut, maka tidak akan ada bidak lawan yang bisa menyerangnya. Hal tersebut dikarenakan proses menyerang hanya dilakukan di bagian jalur serang saja. Namun semakin lama bidak berdiam diri di titik tersebut, maka semakin besar peluang pihak tersebut cepat kalah. Hal tersebut dikarenakan adanya sistim bergilir atau bergantian dalam bermain. Sedangkan bidak yang sudah berada di titik aman, harus 
berpindah ketika mendapat giliran. Jika ia berpindah satu titik saja ia sudah berada di jalur serang dan siap diserang oleh pihak lawan. Hal itu dikarenakan titik aman tersebut terletak atau dikelilingi jalur serang. Sehingga satu langkah ia bergerak maka ia akan memasuki jalur serang. Di mana pihak lawan sudah siap di jalur serang.

\section{Define / Menetapkan}

Dari sisi gameplay, terdapat kekurangan yang membuat game ini akan langsung tidak seimbang jika salah satu pemain mengalami kondisi yang sudah djelaskan di atas sehingga pemain yang menempati titik amain tidak lagi memiliki kesempatan lagi.



Gambar 9. Kotak yang menunjukkan kondisi mati.

[[Sumber: Penulis]

Berdasarkan gambar 9 di atas, dapat dilihat jika bidak dalam kondisi berhenti di kotak A dan Kotak B, maka, sedangkan bidak lawan (yang berada di kotak C) telah berada di jalur serang maka sulit bagi bidak yang berada di area kotak $A$ dan B untuk keluar dengan selamat. Karena setiap kali bidak di dalam kedua kotak tersebut melangkah secara vertikal maupun hirizontal, sudah ada bidak di kotak $\mathrm{C}$ yang akan langsung menyerang bidak yang menapaki jalur serang tersebut.

Selain itu dalam kondisi awal ini, pemain baru bisa mulai menyerang lawan pada giliranya yang ke-4. atau jika dihitung dalam langkah dua pihak pemain, kedua pihak pemain baru bisa melakukan serangan pada langkah ke-7. Hal ini masih terbilang terlalu lama untuk sebuah permainan. Belum lagi jika pemain adalah pemain baru, maka langkah untuk saling memakan bisa lebih lama lagi. Bahkan dalam beberapa kasus setelah 10 langkah belum ada dua belah pihak yang bisa saling serang dikarenakan jalur serang tersebut tertutup.

Berbeda dengan catur, objektif dari permainan ini adalah saling serang hingga tidak ada permainan yang tersisa. Sehingga variabel strategi hanya tetuju pada penghabisan bidak lawan. Penambahan variabel objektif akan memberikan dua varibel strategi yang berbeda, sehingga memungkinkan untuk mengembangkan permainan lebih dinamis. 


\section{Ideation / Perumusan ide}

Dari proses pengamatan dan identifikasi permasalahan yang ada, peneliti memberikan beberapa rumusan solusi untuk pengembangan permainan ini. Di antara alternatif pemecahan masalah tersebut di antaranya adalah dengan cara:

1) Penambahan Aturan Bertumpuk

Untuk menghindari posisi mati seperti yang dijabarkan pada poin di atas, maka peneliti memberikan alternatif solusi, sehingga jika dalam permainan ditemukan kondisi di mana ada 4 bidak yang terjepit di sudut area tetap bisa berjalan sebagaimana mestinya. Penambahan aturan tersebut adalah dengan diadakanya aturan bertumpuk dan turun tumpuk. Sehingga diperlukan bentuk bidak yang memungkinkan untuk dilakukan penumpukan.
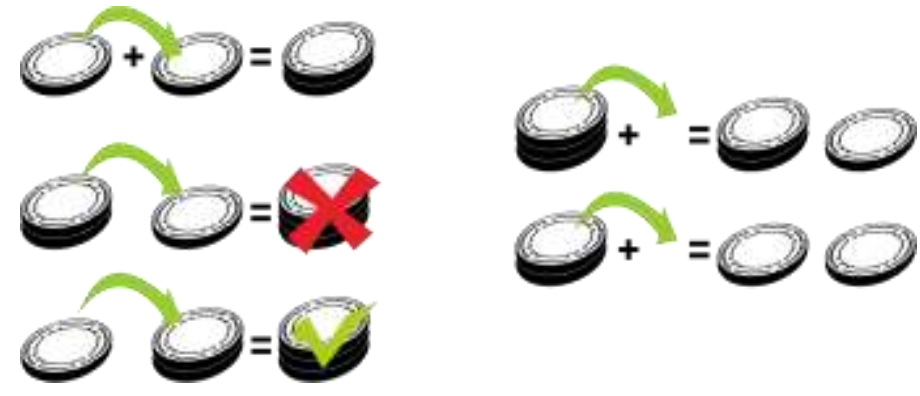

Gambar 10. Aturan menumpuk

[Sumber: Penulis]

Konsepnya adalah membuat peraturan di mana satu bidak dan bidak lainya dapat saling bertumpuk, dengan maksimal tumpukan 3 bidak. Sehingga dalam kondisi terjepit seperti di atas, ke empat bidak ang tersudut dapat bertumpuk terlebih dahulu sebelum menyebrang ke jalur serang yang mengunci lokasi mereka. Bidak yang bertumpuk hanya bisa dikalahkan dengna bidak lainya yang bertumpuk dengan jumlah minimal sama, atau lebih besar dari tumukan bidak yang hendak diserang. Namun demikian, untuk dapat menumpuk, atau menurunkan tumpukan, pemain hanya bisa melakukanya satu kali dalam satu giliran. Sehingga dalam setiap giliran permainan pemain hanya bisa memili 1 dari 4 aksi yang tersedia yaitu, melangkah, menyerang, menumpuk, atau menurunkan tumpukan saja. Untuk menjaga keseimbangan permainan, dalam peraturan bertumpuk, bidak bertumpuk manapun yang telah memakan bidak lawan, diharuskan untuk berpencar kembali menjadi satuan bidak.
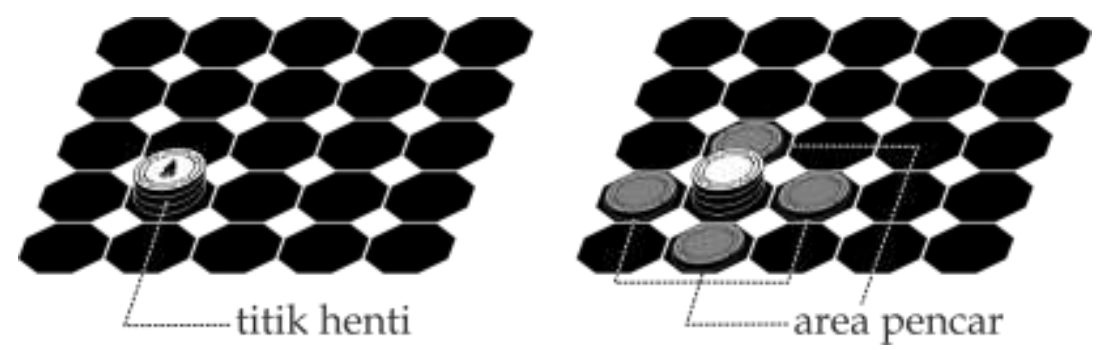

Gambar 11. Aturan memecah bidak tumpukan yang telah menyerang

[Sumber: Penulis] 
Dengan adanya peraturan ini, waktu tunggu untuk mencapai posisi saling menyerang bisa dipersingkat. Jika sebelumnya setiap pemain harus menunggu hingga giliran ke-4, atau setelah 7 kali giliran permainan kedua pemain baru bisa saling serang, dengan adanya sistem tumpuk ini kedua pemain bisa saling serang hanya dalam dua langkah, yaitu penyerangan dapat mulai dilakukan pada langkah ke tiga setiap pemain. Atau setelah 5 langkah pergantian giliran.

\section{2) Penambahan Petak Singgasana}

Terkait dengan objektif permainan yang hanya bertujuan untuk menghabiskan bidak lawan saja. Dengan menambahkan variabel kesempatan menang, objektif permainan tidak hanya tentang menghabiskan bidak lawan, namun juga mengejar kondisi di mana pemain bisa memenangkan permainan tanpa harus menghabiskan bidak lawan.

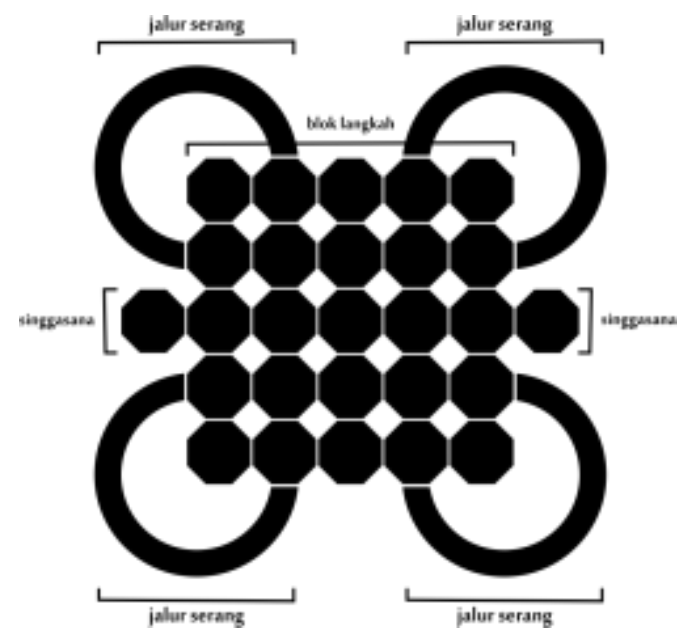

Gambar 12. Bentuk usulan pembaharuan arena permainan

[Sumber: Penulis]

Dalam proses pengamatan, peneliti memberikan unsur penambahan elemen permainan pada area singgasana sebagai tempat peletakan simbol kemenangan (bisa bendera ataupun raja). Sebagaimana dalam sistem catur, permainan berakhir pada saat pemain lawan terlah berhasil memojokkan raja. Hal tersebut dapat diadaptasi dalam permainan ini. Sehingga tuuan utama dari permainan tersebut adalah untuk mendapatkan simbol tersebut. Baik dengan cara menghabiskan bidak terlebih dahulu, maupun mengambil simbol bahkan sebelum bidak habis. Konsep ini akan membuka peluang strategi dalam bermain lebih luas.

\section{Prototype / Purwarupa}

Prototype yang dirancang terjadi pada pada bidak dan arena permainan, serta kotak kemasan yang menjadikan permainan ini mudah untuk dibawa dan dikenalkan kepada pemain lainya. 
1) Bentuk bidak

Jika di awal bidak hanya dibutuhkan dua jenis saja pembeda antara pasukan satu dan pasukan lainya. Untuk proses variatif permainan, maka ditambahkan satu lagi desain bidak yang berperan sebagai bendera panji yang harus dilindungi tiap pasukan. Sehingga dalam satu set permainan terdapat dua kubu pasukan di mana tiap kubu terdapat 14 jumlah prajurit bidak dan 1 bendera panji. Sehingga dalam satu permainan masing masing pemain memegang 15 bidak yang ada di arenanya.


Gambar 13. Contoh visual bidak permainan simbol dan pasukannya.

[Sumber: Penulis]

2) Bentuk papan permainan

Berkaitan dengan pengembangan permainan dengan menambahkan satu petak yang berfungsi untuk meletakkan bendera simbol kerajaan, maka tampilan desain papan permainan ditambahkan satu petak untuk peletakan simbol sebagai berikut;

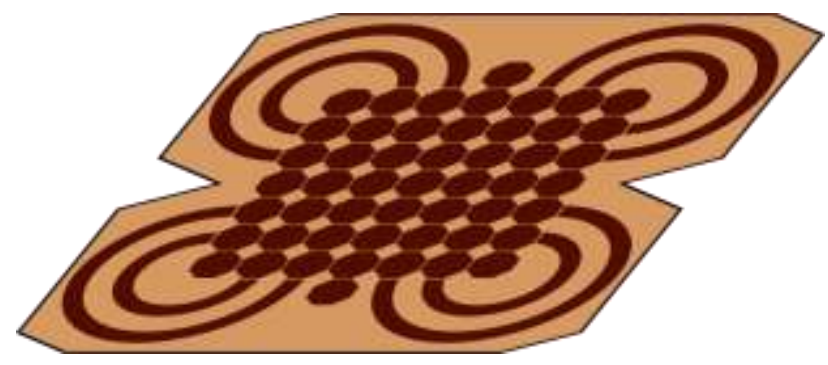

Gambar 14. Visual sederhana papan permainan.

[Sumber: Penulis]

\section{Test / Uji Coba}

Dalam proses uji coba, peneliti mengemas hasil penyesuain permainan dalam bentuk cetak untuk memudahkan responden dalam melakukan uji coba permainan. Proses selanjutnya, yaitu perumusan elemen redesain dari permainan tradisional konvensional menjadi permainan board game yang lebih relevan.

Peneliti memanfaatkan event yang memiliki potensi masa yang banyak sehingga responden akan beragam. Terdapat dua event yang dijadikan tempat penelitian, event pertama adalah pada saat Car Free Day yang biasa dilakukan di Bundaran $\mathrm{HI}$, dan satu lagi event Pakoban (Pasar Komik Bandung) yang merupakan acara kegiatan budaya populer. 

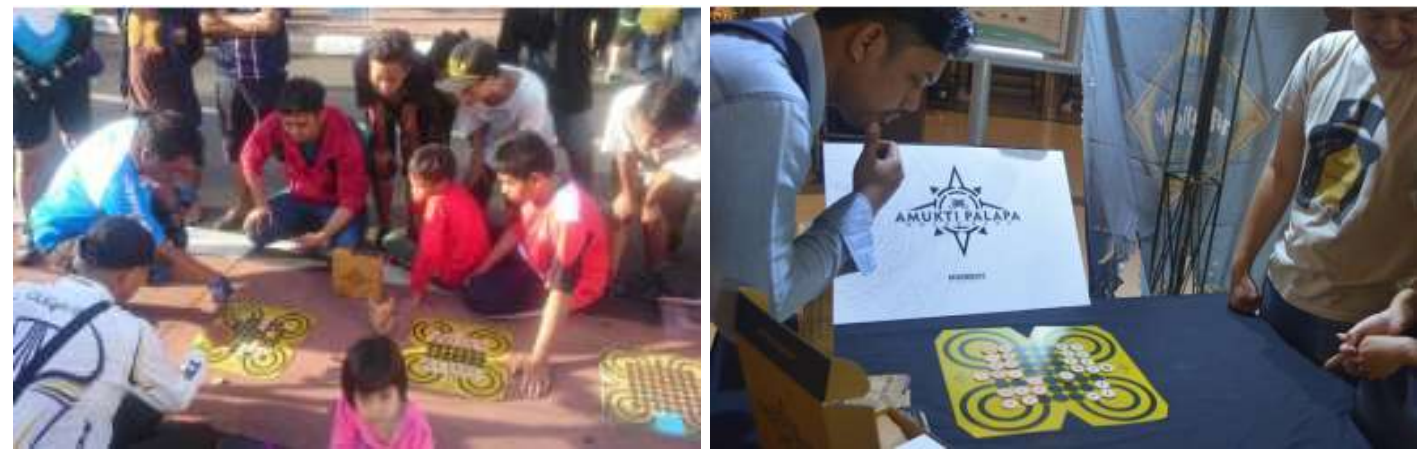

Gambar 15. (kiri)Kegiatan bermain dengan segmentasi umum di Car Free Day Bundaran HI dan (kanan) kegiatan pameran di pasar komik Bandung /Pakoban

[Sumber: Penulis]

\subsection{Analisis permainan dalam model ATUMICS}

Dalam proses perancangan ulang permainan tradisional Bas-basan Sepur ke dalam bentuk permainan papan modern / board game, maka dapat dijabarkan sebagai berkut:

1. Level Mikro

1) Technique

Dalam konteks ATUMICS, teknik yang dimaksud adalah teknik pembuatan produk. Jika dikaitkan dengan konteks permainan bas-basan sepur, maka teknik pembuatan permainan ini tergolong sangat sederhana karena hanya perlu menyiapkan bidang yang akan diberi gambar pola papan (jaman dahulu menggunakan tanah halaman) dan menyiapkan bidak sebagai elemen permainan (biasanya berupa batu kerikil).

\section{2) Utility}

Kegunaan permainan ini selain untuk bermain dalam mengisi waktu luang dan belajar melalui nilai filosofis permainan dalam mengalahkan lawan, sedekat apapun bidak kita dengan bidak lawan, namun jika tidak ada peluang untuk menyerang, bidak lawan tidak akan bisa diserang. Namun sejauh apapun jika berada di jalur yang tepat, maka memungkinkan pemain untuk mengalahkan bidak lawan meski jauh.

\section{3) Material}

Bahan yang digunakan untuk memainkan permainan ini hanyalah tanah atau bidang di mana pemain bisa menggambar pola arena permainan dan bida-bidak pasukan yang berbeda antara pasukan satu dan lainya yang masing-masing sebanyak 14 bidak.

4) Icon

Bentuk ikonik yang ada dalam permainan ini yang membedakan dengan permainan lainya adalah bentuk arena permainan dengan empat lingkaran serang di empat sudut sisi arenanya yang menyerupai daun semanggi. 


\section{5) Concept}

Menurut Khamadi et al. (2015), Bas-basan sepur merupakan permainan papan yang sejenis dengan permainan catur yang dikenal masyarakat saat ini, yang membutuhkan konsentrasi dan logika berfikir pemain untuk menentukan strategi terbaik melawan pemain lainnya. Selain itu permainan ini memiliki keunikan tersendiri pada arena dan aturan permainannya yang harus melewati jalan melingkar. Permainan ini hampir menyerupai catur dengan menandingkan dua sisi kelompok pasukan dalam sebuah arena, namun yang membedakan adalah aturan gerak dan cara serangnya.

6) Shape

Unsur bentuk dalam permainan ini terfokus pada dua hal, yaitu bentuk pola arena permainan yang khas dengna lingkar serangnya, dan bidak yang dapat diambil dari benda-benda sekitar yang bisa membedakan antara pasukan satu dan lainya. Dalam permainan aslinya, permainan ini dilakukan di atas tanah yang digambar sebuah pola arena permainan.

Dari penjabaran di atas, maka secara sederhana pemetaan permainan tradisional Bas-basan Sepur dapat dilihat menjadi bagan sebagai berikut:

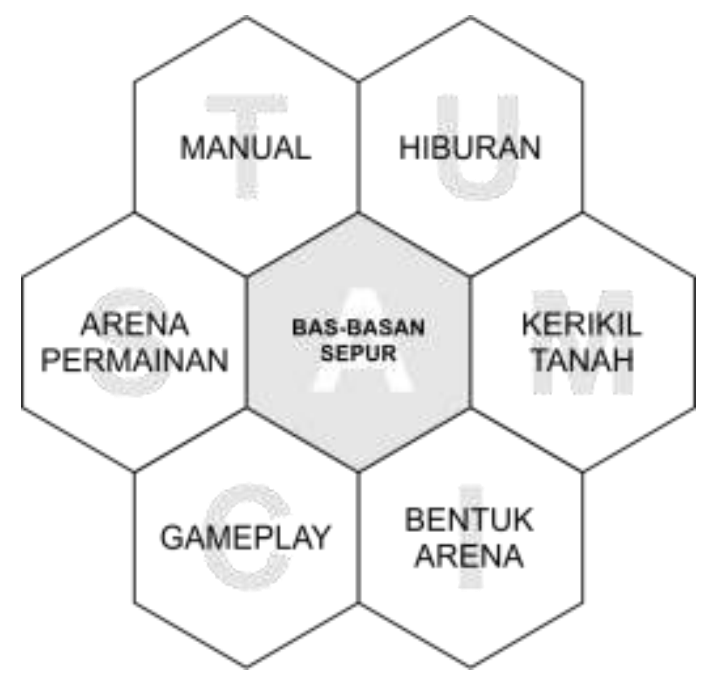

Gambar 16. Tampilan sementara permainan untuk test play

[Sumber: Penulis]

\section{Level Makro}

Pada pemetaan level makro permainan ini, dapat djabarkan ke dalam tiga poin penting sebagai berikut:

1) Motivasi utama

Mengacu pada permasalahan utama penelitian adalah tentang popularitas permainan ini yang berdampak pada keberlangsungan permainan ini ke depan. Sehingga aspek utama dalam level makro ini adalah motivasi Budaya, di mana dengan bentuk yang sekarang, permainan ini belum begitu dikenal di kalangan masyarakat khususnya anak-anak. 
2) Motivasi sekunder

Motivasi sekunder dari permainan ini adalah motivasi sosial. Di mana permainan dan proses pengemasan permainan tradisional saat ini lebih cenderung ke arah digital. Menurut Bredekamp dan Copple dalam Pica (2012: 9-10) bermain menyediakan suatu konteks bagi anak-anak untuk melatih keahlian yang baru diperoleh, dan juga untuk memfungsikan kapasitas berkembang mereka pada peran sosial baru, usaha atau tugas yang menantang, dan menyelesaikan masalah kompleks yang mereka mungkin tidak lakukan

3) Motivasi lainya

Motivasi lainya adalah motivasi ekonomi. Di mana permainan ini memiliki potensi untuk dikembangkan dengan cara dikemas ulang menjadi salah satu bagian dari produk industri kreatif yang berpotensi menjadi ikon permainan lokal.

\subsection{Perancangan Purwarupa / Prototype}

Berdasarkan analisa dari metode Design Thinking disimpulan terdapat beberapa perombakan dalam permainan tradisional dengan menambahkan aturan permainan, modifikasi arena permainan, hingga pertimbangan visual dan pengemasan permainan tersebut yang fokus pada bentuk permainan papan /board game (bukan digital). Berdasarkan acuan model ATUMICS, permainan tradisional Bas-basan Sepur akan dijabarkan dalam model yang sama, begitu juga dengan garis besar gambaran penjabaran board game yang dituju sebagai model trasformasi. Dari dua penjabaran itu maka didapat bentuk bagan sebagai berikut:
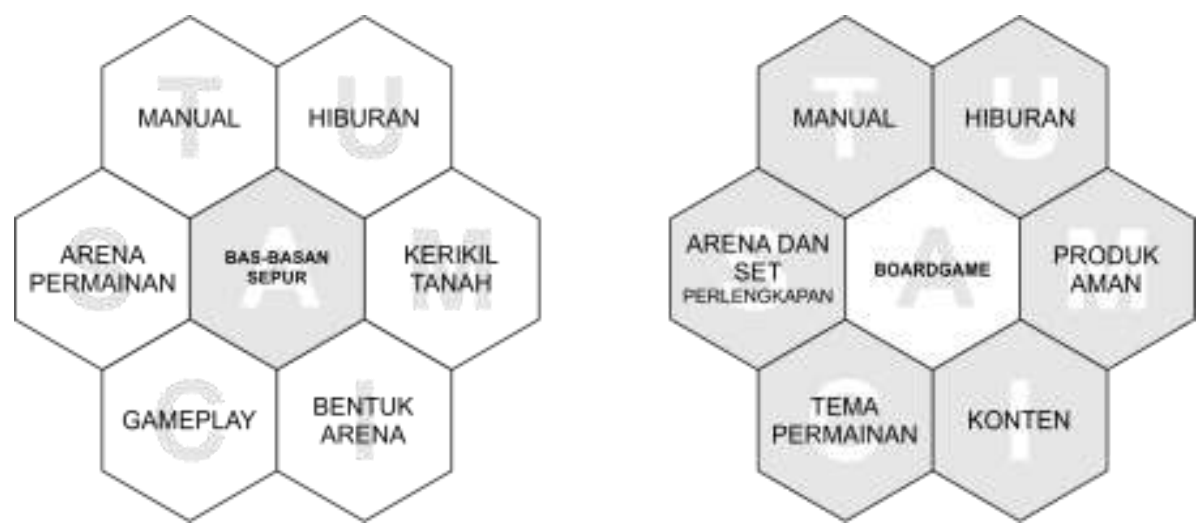

Gambar 17. Hasil data prosentasi tanggapan tentang permainan [Sumber: Penulis]

Dari penjabaran di atas, dipilih elemen yang memiliki dampak signifikan dalam proses perancanganya. Elemen yang memiliki dampak signifikan dalam perancangan adalah elemen AMICS (Artefact, Material, Icon, Concept, dan Shape). Lebih rinci lagi elemen tersebut akan disandingkan satu sama lain untuk mengetahui perbandingannya sebagai berikut: 

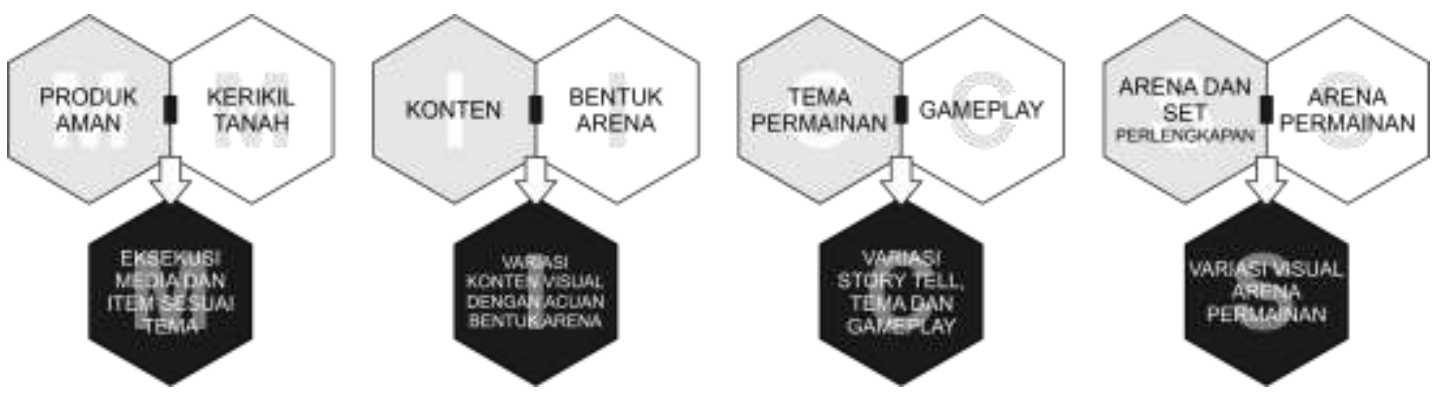

Gambar 18. Hasil data prosentasi tanggapan tentang permainan

[Sumber: Penulis]

Sehingga dari penjabaran di atas dapat disimpulkan bahwa elemen yang harus diperhatikan pada saat melakukan redesain adalah dengan mengolah konten Artefact: Material/bahan, Icon/Ikon, Concept/konsep, dan Shape/bentuk yang bisa dirangkai dalam akronim AMICS.

Dari penjabaran tentang strategi yang dapat dilakukan untuk meredesain permainan ini ke dalam bentuk permainan papan yang lebih representatif dengan era saat ini, maka peneliti membuat purwarupa permainan dengan naman permainan papan Amukti Palapa. Pemilihan nama Amukti Palapa sendiri terinspirasi dari penelitian Khamadi et al. (2015) untuk mempopulerkan kembali permainan tradisional ini ke dalam bentuk digital. Sehingga diharapkan, dengan menggunakan satu branding nama yang sama dengan penelitian sebelumnya, pengguna dapat lebih familiar dengan nama tersebut.

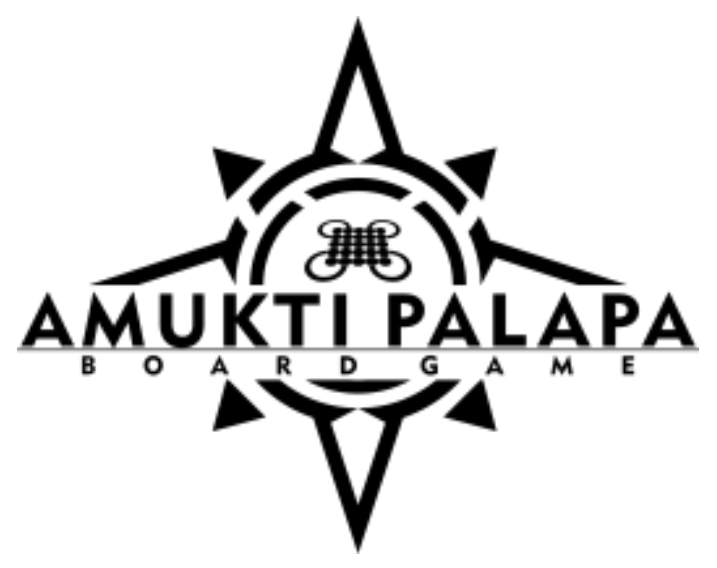

Gambar 19. Logo visual permainan amukti palapa sebagai bentuk prototype [Sumber: Penulis]

Berikut ini adalah tampilan purwarupa berupa satu set pengemasan permainan papan beserta buku panduan yang menjadi dasar potensi pengembangan nantinya. 



Gambar 20. (atas) Purwarupa bidak permainan, pengemasan, dan tampilan visual (bawah) Purwarupa kotak dan pengemasan permainan

[Sumber: Penulis]

\section{Kesimpulan}

\subsection{Mengapa Permainan Ini Tidak Populer}

Dari penelitian yang dilakukan menggunakan metode Design thinking oleh Brown dan Wyatt (2010). Melalui alur Empati - menentukan - merumuskan ide - membuat prototype - melakukan testplay, maka dilakukanlah sebuah uji coba tidak hanya dengan responden yang telah ditentukan, namun juga dengan responden terbuka yang ditemui di beberapa event, dan kesempatan biasa dengan cara mengajak bermain dan meminta masukan mereka. Dari sana dapat disimpulkan bahwa penyebab pemrainan ini tidak begitu populer adalah:

1) Bas-basan Sepur tidak begitu populer di kalangan remaja dan hanya beberapa orang tua saja yang mengetahui tentang hal ini. Hal ini dikarenakan adanya perbedaan zaman. Di mana jaman dahulu anak-anak selalu bermain di luar dan di halaman lalu menggambar pola arena dan memainkan permainan ini di tanah lapang dengan menggunakan kerikil atau benda kecil lainya. Sedangkan di jaman sekarang anakanak khususnya area perkotaan tidak biasa bermain di luar seperti dahulu.

2) Dari sisi gameplay terdapat beberapa kekurangan yang berpotensi mengurangi daya tariknya yaitu, proses penyerangan yang baru akan terjadi pada langkah ke-7. Juga kondisi yang membuat permainan tidak seimbang ketika salah satu pemain dalam kondisi terkunci pada titik aman di bagian sudut arena.

3) Dari sisi branding, permainan ini belum terbranding dari segi visualisasi hingga pengemasan yang menjadi poin penting dalam brand. 


\subsection{Bagaimana Cara Perancangan Pengemasan yang Relevan}

Untuk menjawab pertanyaan ini, peneliti menggunakan model ATUMICS dari Nugraha (2012). Dari model ATUMICS dirumuskan unsur AMICS sebagai unsur yang harus diperhatikan dalam meredesain/ mengembangkan permainan ini ke depannya. Dengan melakukan pembandingan antara permainan tradisional Bas-basan Sepur dan permainan papan / board game. Maka dirumuskan bagan sebagai berikut:

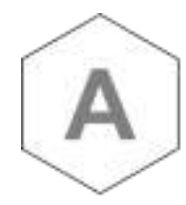

BAS-BASAN SEPUR

PERMAINAN PAPAN

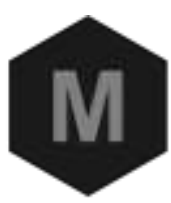

EKSEKUSI MEDIA DAN

ITEM SESUAI TEMA

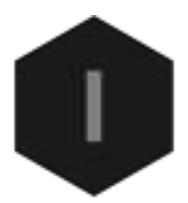

VARIASI

KONTEN VISUAL

DENGAN ACUAN BENTUKARENA

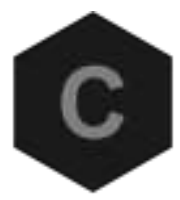

VARIASI STORY TELL TEMA DAN GAMEPLAY



VARIASI VISUAL

ARENA

PERMAINAN

Gambar 21. Acuan utama dalam meredesain Bas-basan Sepur

[Sumber: Penulis]

Dari poin unsur di atas dapat disimpulkan bahwa untuk melakukan redesain yang baik sesuai dengan karakter permainan ini adalah dengan memperhatikan konsep AMICS, yaitu faktor Artefact/produk, Material/Bahan, Icon/Ikon, dan Shape/bentuk. Sehingga dari acuan tersebut dapat dilakukan eksplorasi konten seduai dengan tema dan tampilan visual yang sesuai dengan segmentasi di eranya. Berikut ini adalah contoh alternatif pengembangan perancangan produk permainan papan dengan acuan AMICS:

Tabel 1. Tabel arah perancangan dalam redesain permainan Bas-basan Sepur [Sumber: Penulis]

\begin{tabular}{|c|l|l|l|}
\hline No & Unsur & \multicolumn{1}{|c|}{ Keterangan } & \multicolumn{1}{|c|}{ Arah Redesain } \\
\hline 1 & & $\begin{array}{l}\text { Artefact/artifak: } \\
\text { Permainan tradisional Bas-basan Sepur. }\end{array}$ & $\begin{array}{l}\text { Artefact/artifak: } \\
\text { Permainan papan (board game) } \\
\text { dari sisi visual branding. }\end{array}$ \\
\hline 2 & $\begin{array}{l}\text { Material/bahan: } \\
\text { Papan arena (Tanah), Bidak (batu } \\
\text { kerikil/biji-bijian). }\end{array}$ & $\begin{array}{l}\text { Material/bahan (alternatif) } \\
\text { Clipboard, karton, kayu, akrilik, } \\
\text { dan lain-lain. }\end{array}$ \\
\hline 4 & $\begin{array}{l}\text { Icon/ikon: } \\
\text { Gambar arena 7x7 petak dengan garis } \\
\text { lingkar serang di empat sudutnya. }\end{array}$ & $\begin{array}{l}\text { Icon/ikon: } \\
\text { Mempertahankan ikonik jalur } \\
\text { serang dalam arena. }\end{array}$ \\
\hline 5 & $\begin{array}{l}\text { Concept/konsep: } \\
\text { Pertarungan antar dua kubu pasukan. }\end{array}$ & $\begin{array}{l}\text { Concept/konsep: } \\
\text { Eksplorasi tema kerajaan, } \\
\text { kelompok ras mitologi, dan } \\
\text { lain-lain }\end{array}$ \\
\hline & $\begin{array}{l}\text { Shape/bentuk: } \\
\text { Permainan papan dan bidak kedua kubu } \\
\text { pasukannya. }\end{array}$ & $\begin{array}{l}\text { Shape/bentuk: } \\
\text { Bentuk permainan bisa } \\
\text { divariasi dari 2 orang menjadi } \\
\text { kelompok. }\end{array}$ \\
\hline
\end{tabular}


Dengan demikian, diharapkan penelitian ini dapat menjadi salah satu rujukan dalam mengeksplorasi kekayaan budaya Indonesia khususnya di bidang permainan tradisional dalam upaya mempopulerkan kembali permainan tradisional dan mengemasnya dalam bentuk board game dalam konteks peningkatan diversifikasi produk di bidang industri kreatif.

\section{DAFTAR PUSTAKA}

Browan, Tim dan Jocelyn Wyatt. (2010). Design thinking for social innovation. Stanford Social Innovation Review Winter. STANFORD. Graduate School of Business.

Khamadi, K., \& Senoprabowo, A. (2016). Model Adaptasi Permainan Papan Tradisional Macanan Ke Dalam Perancangan Permainan Digital. ANDHARUPA, 2(2), 167180.

Khamadi, K., Sihombing, R. M., \& Ahmad, H. A. (2015). Perancangan Konsep Adaptasi Permainan Tradisional Bas-Basan Sepur dalam Permainan Digital "Amukti Palapa." Jurnal Komunikasi Visual WIMBA, 5(2).

Lin, R., Chen. C.T. (2012). A discourse on the construction of a service innovation model: focus on the cultural and creative industry park. In: Ifinedo, P. (ed.) EBUSINESS-Application and Global Acceptance, pp. 119-136. Croatia, InTech

Lin, R., Hsieh, H.-Y., Sun, M.-X., Gao, Y.-J. (2016). From Ideality to Reality- a case study of mondarian style. In: Rau, P.-L.P. CCD2016 LNCS, pp. 365-376, Switzerland

Misbah, I.H. (2007). Peran Permainan Tradisional Yang Bermuatan Edukatif Dalam Menyumbang Pembentukan dan Identitas Bangsa. Bandung: IPI.

Nugraha, A. (2012). Transforming Tradition: A Method for Maintaining Tradition in a Craft and Design Context. Helsinki: Aalto University, School of Arts, Design and Architecture, Finland.

Pica, Rae. (2012). Permainan-Permainan Pengembang Karakter Anak-Anak. Jakarta: PT. Indeks

Ralibi, Raymond, Achmad Syarief, dan Irfansyah. (2016). Perancangan mobile game berdasarkan permainan tradisional rakyat "Dodombaan" untuk membangun interaksi sosial antar pemain, Serat Rupa Journal of Design,Vol.1, No.2:289300. 